\title{
Gender Justice Discourse in the Educational System of Afghanistan during the Democracy Period (2001 - 2015)
}

\author{
Davood Sokhanwar \\ Ibn-e-Sina University, Kabul
}

\begin{abstract}
This study seeks to examine Afghan women's access to education (gender justice) in the wake of September 11 amid developments and efforts made to establish democracy in this country in the years between 2001 and 2014. Using discourse analysis, this research aims to extract one nodal point and several floating signifiers to explore a semantic system of gender justice, albeit by making use of examples taken from the educational system during the mentioned period. The data collected in this research are extracted from texts concerning the role of women in education in Afghanistan in the mentioned period. Its importance in terms understanding the intellectual and political atmosphere of the mentioned political system especially in respect of women's access to their educational rights is brought to light. This study concludes that the gender equality index is satisfactory to a great deal in the present government as compared to the period of Taliban in which the index was lowest in the world. However, the present government has not achieved success as much as it was expected because gender justice discourse has not become hegemonic in Afghanistan. The reason for the unsuccessfulness of the discourse lies in the elements that make the discourse hegemonic. Because elements could not play their effective role, this discourse did not become hegemonic.
\end{abstract}

Keywords: Gender, Discourse, Educational System, Afghanistan.

\section{Introduction}

Women's right to education (gender justice in education) has always been considered as one of the most challenging issues in the social and political history of Afghanistan. The issue has been more serious at particular points in the history of the country. The present article examines gender justice in Afghanistan after the fall of the misogynist Taliban regime (19962001) and following the formulation of the new Afghan government. This period has been described as the democracy period in the history of Afghanistan because a relatively open political space was created in the period and there were more opportunities for women to participate in various political and social arenas. Laws adopted to protect women's rights in the period, paved the way for changes in women's political and social lives. The author of the present paper seeks to answer the following questions: What constitutes the signifiers in the semantic system of Afghanistan's gender justice discourse from the perspective of discourse analysis? What nodal point does the mentioned discourse revolve around? What elements constitute its floating signifiers?

The method and the theoretical basis of the research is discourse analysis as employed by Chantal Mouffe and Ernesto Laclau. In 1985, they published Hegemony and Socialist Strategy: Towards a Radical Democratic Politics, in which they expanded Foucault's theory of discourse analysis and applied it to all political and social affairs. According to Laclau and Mouffe, discourse is the structured whole achieved through articulation. This method is significant when studying social issues because it identifies and analyzes various discourses, elements, signifiers, changes, developments, and growth, as well as their becoming hegemonic and declining in different periods. We have employed discourse analysis in order to analyze gender justice as a discourse in the mentioned period and formulate it as a structured whole. The formulation is reached by first checking the signs and signifiers that contribute to the formulation and to the creation of the semantic system. A nodal point is then derived from the floating signifiers, which can lead the reader to facts according to Laclau and Mouffe's discourse analysis. A nodal point is a sign around which other signs are ordered. Floating signifiers are signs to which competing discourses attempt to assign meaning(Laclau and Mouffe, 2001). 


\section{Discursive Formulation}

Formulation is placing the elements and signifiers of a discourse together so that a new identity is created in the new set (Phillips and Jorgensen, 1389) and a new discourse is created that leads to new forms of social order(Norval and Stavrakakis, 2000). In this section, will be discussed the articulation of gender justice in the democratic period to uncover the formulation and creation of the new semantic system in the field of gender justice. First will be discussed the development of the nodal point and then address the arrangement of elements and floating signifiers that indirectly contribute to the discourse's becoming hegemonic.

\section{The Nodal Point; Democracy-Centered Education}

The centrality of the democracy signifier is evident in the text of the Bonn Agreement, the new constitution, the statements of politicians, the Loya Jirga talks on the constitution and parliamentary and presidential elections. According to Article VI of the constitution, the realization of democracy is one of the obligations of the government (Government Media \& Information Center website). School textbooks praise a government based on democracy as the protector of the rights and freedom of human beings (Ministry of Education, 1390,65). Textbooks also discuss gender inequality and criticize gender injustice, which is attributed to people's ignorance and lack of a healthy religious education (the Ministry of Education, 1390, 67).Women benefit from democracy-centered education because it treats all the members of society equally and does not favor any particular individual.

President Hamid Karzai's statements in the Loya Jirga talks on the constitution are considerable from the perspective of discourse analysis because the discourse dominating women's education can be inferred from them. In part of his speech, he describes the political and social situation in Afghanistan after the Taliban as follows:

"After the fall of the Taliban and the establishment of the Islamic State of Afghanistan, civil and political liberties and human rights of the Afghan people were established... An open political space emerged for assembly and expression of views. After several years of violations of women's rights, Afghan women reclaimed their status in various areas of national life. The rights of women and girls to work and education were guaranteed. Today, the Afghan woman enjoys all civil and human rights and necessary freedoms in the light of the teachings of Islam and the cultural values of our country "("Anis Newspaper," 2003).

It is clear that, at the beginning of the text, the new government, which is contrasted with the former regime (the Taliban), has achievements such as civil and political liberties and human rights, all of which can be realized in a democratic atmosphere. The signifier of freedom of speech has been praised as an important symbol of democracy. When discussing women, women's freedom, the right to work and education and enjoyment of all civil rights have been emphasized. This emphasis is a criticism of the former dominant discourse, in which women enjoyed no rights, even the right to education. The mentioned text marginalized discourse of the earlier state as a "violation of women's rights" and as a deterrent to democracy, and attempts to represent it negatively. He praises the ratification of the constitution as a new era of equality, freedom, and equal rights and seeks to represent it positively. In addition, the emphasis on the violated rights of women represents the transition of the society from the old discourse to the new discourse in which women's activities, particularly their access to education, are based on democratic values in a way that equal access to education will become an axiom.

\section{The Development signifier in educational structures}

\section{Basic Training}

In this arena, the performance of the Ministry of Education concerning the education of girls has been regarded as satisfactory. From a quantitative perspective, the number of students has increased dramatically in recent decades. At the beginning, the government launched a campaign to encourage children to return to school and to support girls' education. Because of this program, girls were significantly more interested in attending school. While the number of female students in 2001 was only 5000, this figure rose to 2.7 million in 2010 ("Equal Rights, Unequal Opportunities,", p. 23). According to UNESCO, the gender justice index in Afghanistan under the Taliban was the lowest among world nations, but in 2010, it rose to $79 \%$. As a result, the county's GPI increased from 0.08 to 0.69 ("from access to equality,", p. 108). In its National Strategic Plan (NSP) from 2010 to 2014, the country's Ministry of Education predicted the enrollment of ten million children in schools as well as a $72 \%$ to $90 \%$ increase in the enrollment rates of girls by the year 2014 . Although the prediction did not come true as hoped for, the enrollment rate of students (both male and female) reached about 8.6 million in 2013 and 
9.2 million 2015 ("Afghanistan Ministry of Education, National Educational Strategic Plan III,", p. 19)(Ministry of Education, $2017,19)$. This situation represents a relative progress.

\section{Teacher Training}

The number of registered male and female students has continually increased since 2001. Consequently, demand for new teachers increased to the extent that the number of teachers increased by about eight times from 2002 to 2008 . While according to one statistic, approximately 20700 teachers worked in the public education system in 2002 in all schools (from 1st to 12th grade), almost all of whom were male. According to a report by the Ministry of Education, the results of an assessment show that the number of female teachers rose to 29.22\% in 2008 (Ministry of Education, 2009 quoting Beiza 2013, 211) and to $33 \%$ in 2015.

In this area, the government lacked not only enough teachers but also enough teacher training centers. The Ministry of Education (2015) reported that most girls dropped out of school because of a lack of female teachers. Hence, the ministry employed the best "existing candidates" strategy, especially for the recruitment of female teachers in rural areas. According to this strategy, women interested in serving as teachers in local schools and deprived areas are identified and recruited even if they do not meet the basic criteria. In addition, if these women demonstrate a formal commitment to participation in job improvement and professional development programs as teachers or administrative officers, the Ministry of Education would be committed to paying them subsistence allowance for pursuing higher education and providing educational materials.

\section{Vocational Training}

Equal access by all social groups, especially the socio-economically disadvantaged, is part of the main objectives of the national strategy for vocational education and training. Although female students are much less interested in the field due to the low status of the discipline in the country as well as the low employment rates of graduates, according to the Ministry of Education, the enrollment of girls in the field has increased in recent years. In 2001, only about 1,500 male students entered 83 semi-professional schools, but according to the Ministry of Education, the enrollment of female students in 2015 reached $17 \%$, which indicates a relatively small increase compared to equivalent disciplines.

However, there are problems and shortcomings in the discipline that should not be easily ignored. Lack of good teachers, lack of standard curriculum and quality educational materials, lack of equipment, lack of electricity and water have presented challenges for these schools and institutes. However, in 2013 UNESCO declared that efforts to update the curriculum of the discipline and remove the old curriculum continue (Ministry of Education, 2013, 15).

\section{Floating Elements and Signifiers}

Floating elements and signifiers are signifiers articulated around the nodal point in a chain of equivalence in the framework of a specific discourse. They modify and moderate the meanings of the nodal point (Laclau and Mouffe, 2001, 105). Although these elements do not directly assign meaning to the nodal point, they indirectly contribute meaning to the discoursive system. In the discoursive system of democracy in Afghanistan, elements such as women's rights, freedom, and human rights were floating signifiers that contributed to the realization of the discoursive system of gender justice in the country during the mentioned period.

\section{Women's Rights Signifier; Freedom; Human Rights as the Facilitator of Women's Education}

It can be said that only the pro-democracy discourse and the new Afghan constitution allowed women to become presidents, ministers, lawmakers etc. This process may indirectly contribute to women's education. In addition, the government is committed to a large number of human rights treaties and conventions, including the Convention on the Elimination of All Forms of Discrimination against Women (CEDAW), which could have a significant impact on access to education for girls. In the discoursive system of this government, the element of the freedom of citizens was regarded as an axiom to which the government committed itself. Thus, the first article of the Education Act of Afghanistan discusses "providing equal rights to education for all the citizens of Afghanistan through the development of a fair and balanced universal knowledge system, and Article III discusses the equal right of Afghan citizens to education without any kind of discrimination. This is an emphasis on the right to free access to education, which is not limited by any constraints, especially gender. 
These signifiers, which are regarded as axioms in this discoursive system, seem to be opposed to the discourse of the previous Islamists, which was considered as a male discourse that required the head of the state to be male. The discourse of the new government has paved the way for the equal representation of women and men in social arenas. During the Taliban period, elements such as human rights, freedom of women and women's rights were suppressed and the active participation of women in the political arena was systematically prohibited. Women were also denied the right to be part of the formal and informal structure of the government.

From what has been said we can conclude that although the progress made by the Ministry of Education in the area of gender justice has not continued as planned, it has been partly successful. This success should not be ignored given the obstacles faced by the government. If one intends to determine the quality and the number of existing efforts in the democracy period, reviewing the performance of the previous state concerning the education of girls can be a source of credible evidence. At that time, all social infrastructure and educational structures had been destroyed. According to the United Nations, in 2002, only $5 \%$ of Afghan women could read and write (united Nation, 2002). However, the government managed to stop this process gradually.

Therefore, although they might not have achieved the objectives set by the previous strategy, but given the obstacles, such an achievement would be satisfactory. However, a form of gender inequality persists even in the process of making progress. In this process, fewer girls have enrolled compared to boys, they have been less likely to continue and complete their school education, fewer girls have pursued higher education, and some of those who have enrolled have always been absent from classes. Poor school conditions, lack of separate schools for girls in some provinces and rural areas, early marriage, conservative and discriminatory views about education for girls, and insecurity are among the reasons for these problems.

\section{Discussion and Conclusion}

Education based on democratic values became the focal point of the gender justice discourse in the democracy period. The semantic system of this discourse was formulated according to this structure and all the floating elements and signifiers were arranged in this direction. Several important steps were taken in the area of education including membership in associations and international educational conferences such as "Education for All" and "Millennium Development Goals." The government launched a campaign to encourage children to return to school and support the education of girls, which led to positive results. The number of female students in the Taliban era was about 500,000 and the Gender Inequality Index was the lowest among world nations. However, the number of students in Afghanistan reached more than 9 million in $2015,39 \%$ of which were female.

In this regard, some internal deficiencies hindering the gender justice process should not be ignored. Politicization of educational programs (Kissane, 2012, 16), corruption and inexperience in educational projects not only changed the view of foreign supporters towards a healthy and efficient management but also reduced people's support for the government and diminished their hopes for a serving government. A report by the Sigar Institute about millions of dollars of embezzlement and the government's presentation of fake data about schools that never existed indicates corruption in the Ministry of Education, which has affected women's education negatively (https://www.sigar.mil/pdf/special\%20projects / SIGAR-17-12-SP.pdf). Hence, in terms of discourse analysis, Political operatives failed to perform their roles in the process properly.

Unlike Political operatives, the availability and reliability of the existing discourse appeared to be impressive because the discourse emerged during a power vacuum in the Post-Taliban situation when there was no competition. Therefore, the discourse attempted to produce and reproduce new concepts, which quickly increased its availability. This discourse exploited gaps in the previous discourse concerning women and formulated its discoursive signifiers so that they were acceptable for most individuals especially women. They formulated liberal democracy and human rights signifiers along with Islamic signifiers in such a way that the public, which had a traditional lifestyle, became attracted to them. The formulation also boosted the credibility of the democracy discourse in a traditional society. This action accelerated the movement of the discourse toward becoming hegemonic.

According to what was said, the discourse of gender justice in Afghanistan's democracy period can be called "the discourse of gender justice based on democracy in the post-war intellectual atmosphere." Based on Laclau and Mouffe's method, this discourse can be described as follows: 


\section{References}

[1] Afghanistan Ministry of Education, National Educational Strategic Plan III [WWW Document], n.d. URL http://moe.gov.af/Content/files/24_10_2016\%20NESP\%20III\%20-\%20Dari\%20-\%20FINAL_2.pdf. (accessed 1.9.17).

[2] Civics Class Textbook XI, n.d. . Ministry of Education, Department of Curriculum Design, Kabul.

[3] economic and social council, Commission on the Status of Women, 2002.

[4] Equal Rights, Unequal Opportunities [WWW Document], n.d. URL https://areu.org.af/wp-content/uploads/2016/02/1205EEqual-Rights-Unequal-Opportunities-SP-2012.pdf (accessed 5.24.17).

[5] from access to equality [WWW Document], n.d. URL http://www.uis.unesco.org/Education/Documents/unesco-from-accessto-equality-2012.pdf (accessed 1.9.17).

[6] Kissane, C., 2012. The Way Forward for Girls' Education in Afghanistan. Journal of International Women's Studies 13, 10 28.

[7] Laclau, E., Mouffe, C., 2001. Hegemony and socialist strategy: Towards a radical democratic politics. Verso.

[8] Norval, A.J., Stavrakakis, Y., 2000. Discourse theory and political analysis: Identities, hegemonies and social change. Manchester University Press.

[9] Persian Language and Literature X2, n.d. . Ministry of Education, Department of Curriculum Design, Kabul.

[10] SCHOOLS IN HERAT PROVINCE: OBSERVATIONS FROM SITE VISITS AT 25 SCHOOLS [WWW Document], n.d. URL https://www.sigar.mil/pdf/special\%20projects/SIGAR-17-12-SP.pdf (accessed 5.24.17a).

[11] SCHOOLS IN HERAT PROVINCE: OBSERVATIONS FROM SITE VISITS AT 25 SCHOOLS [WWW Document], n.d. URL https://www.sigar.mil/pdf/special\%20projects/SIGAR-17-12-SP.pdf (accessed 5.24.17b).

[12] The policy of the Islamic State of Afghanistan, 2003. . Anis National Newspaper.

[13] UN Millennium Project | About the MDGs [WWW Document], n.d. URL http://www.unmillenniumproject.org/goals/ (accessed 5.24.17).

[14] Women's Rights, Gender Equality, and Transition: Securing gains, moving forward [WWW Document], n.d. URL https://areu.org.af/wp-content/uploads/2016/02/women-and-Transition.pdf (accessed 5.24.17).

[15] قانون اساسى افغانستان[WWW Document], n.d. URL http://www.gmic.gov.af/pdfs/Afghanistan-constitution.pdf (accessed 5.24.17).

Table
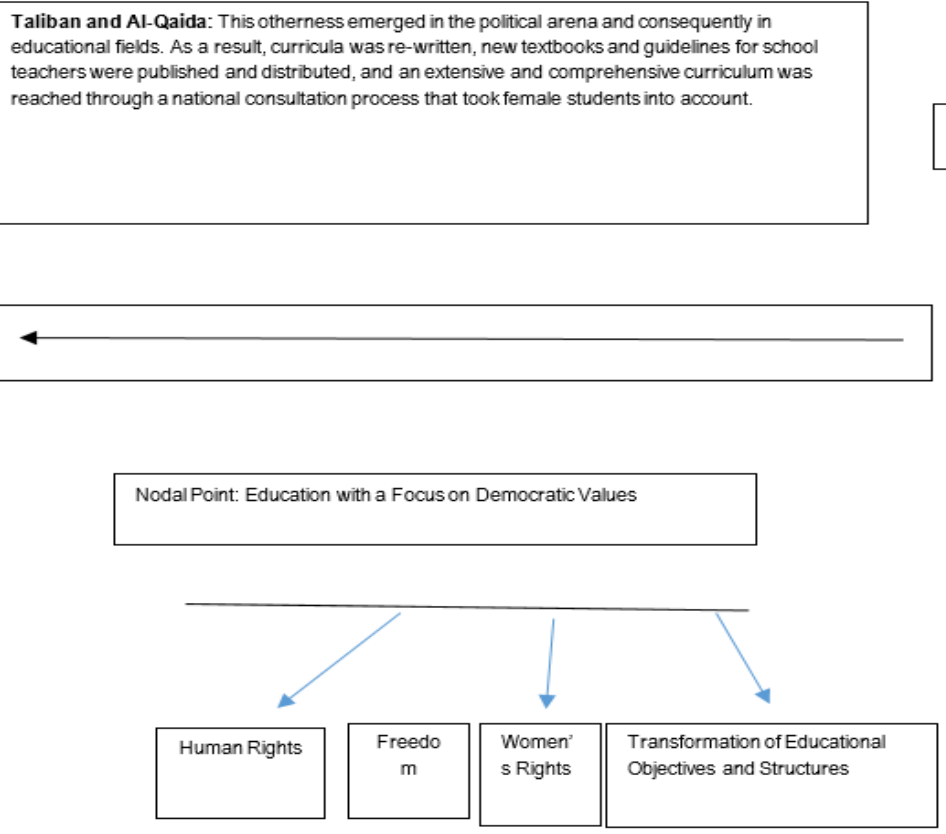